\title{
Participatory design of learning environments: integrating perspectives of students, teachers, and designers
}

Citation for published version (APA):

Konings, K. D., Seidel, T., \& van Merrienboer, J. J. G. (2014). Participatory design of learning environments: integrating perspectives of students, teachers, and designers. Instructional Science, 42(1), 1-9. https://doi.org/10.1007/s11251-013-9305-2

Document status and date:

Published: 01/01/2014

DOI:

10.1007/s11251-013-9305-2

Document Version:

Publisher's PDF, also known as Version of record

Document license:

Taverne

Please check the document version of this publication:

- A submitted manuscript is the version of the article upon submission and before peer-review. There can be important differences between the submitted version and the official published version of record.

People interested in the research are advised to contact the author for the final version of the publication, or visit the DOI to the publisher's website.

- The final author version and the galley proof are versions of the publication after peer review.

- The final published version features the final layout of the paper including the volume, issue and page numbers.

Link to publication

\footnotetext{
General rights rights.

- You may freely distribute the URL identifying the publication in the public portal. please follow below link for the End User Agreement:

www.umlib.nl/taverne-license

Take down policy

If you believe that this document breaches copyright please contact us at:

repository@maastrichtuniversity.nl

providing details and we will investigate your claim.
}

Copyright and moral rights for the publications made accessible in the public portal are retained by the authors and/or other copyright owners and it is a condition of accessing publications that users recognise and abide by the legal requirements associated with these

- Users may download and print one copy of any publication from the public portal for the purpose of private study or research.

- You may not further distribute the material or use it for any profit-making activity or commercial gain

If the publication is distributed under the terms of Article $25 \mathrm{fa}$ of the Dutch Copyright Act, indicated by the "Taverne" license above, 


\title{
Participatory design of learning environments: integrating perspectives of students, teachers, and designers
}

\author{
Karen D. Könings • Tina Seidel • Jeroen J. G. van Merriënboer
}

Received: 27 November 2013/ Accepted: 2 December 2013/Published online: 19 December 2013

(C) Springer Science+Business Media Dordrecht 2013

\section{Introduction}

Instructional design processes aim to improve student learning. Educational designers and teachers use their expertise and experience to create best possible learning environments for students. Students themselves typically do not participate actively in the design process (Rudduck and McIntyre 2007). However, their perceptions of instruction determine their learning behaviour (Entwistle 1991) and hence the effectiveness of learning environments. Therefore, "students should help shape rather than simply be shaped by educational policies and practices" (Cook-Sather 2003, p. 22). Additionally, discrepancies between designers' and teachers' perspectives may inhibit the intended implementation of learning environments. Combining the expertise of different stakeholders can improve the quality of the instructional design process and the resulting learning environments. Therefore, the main aim of this special issue is to bring together research on how to improve cooperation between designers, teachers, and students in the instructional design process and to show important developments in this research field.

\section{Integrating perspectives: need for participatory design}

Although the importance of students' views on educations is largely acknowledged, it is not yet incorporated in designing daily instructional practices. However, if students' perceptions do not match with the intentions of teachers and instructional designers the instruction is likely not to reach its goals: instruction does not directly influence student learning (Doyle 1977), but is mediated by students' interpretations of it. Learning is

K. D. Könings $(\bowtie)$ · J. J. G. van Merriënboer

Department of Educational Development and Research, School of Health Professions Education, Maastricht University, Universiteitssingel 60, 6229 ER Maastricht, The Netherlands

e-mail: kd.konings@maastrichtuniversity.nl 
influenced by habitual ways of learning (Vermetten et al. 2002). A mismatch between designers' intentions and students' interpretations can cause ignorance of (parts of) the learning environment or use in a different way than intended (Elen and Lowyck 1999). Next to effects on quality of learning, there are also psychosocial effects of mismatches as students' satisfaction with instruction is related to their motivation to learn (Könings et al. 2011a; Roeser et al. 2000). The sense of not being heard causes alienation, experiences of anonymity and powerlessness, which contribute to disengagement from school, with possible consequences such as truancy and dropping out of school (Mitra 2004; Smyth and Fasoli 2007).

Improving the congruence between the perspectives of students and those creating the learning environment (i.e., teachers and instructional designers), thus, is likely to improve student learning. Additionally, effectiveness of instructional design can be fostered by improving congruence between the perspectives of teachers and instructional designers. Mostly, teachers are not involved in the design process of instructional innovations. They are expected to implement the design into practice, which can be extremely difficult. It is a challenge to design innovations that are usable, sustainable, and scalable in classrooms for teachers without the help of the instructional designers (Fishman and Krajcik 2003). Teachers might experience failing preconditions with respect to the educational design itself, the school, the students, and their own competencies (see Könings et al. 2007, for an overview). Therefore, it is necessary to improve collaboration between instructional designers and teachers. Alignment and coordination will be improved by an iterative, collaborative design process including multiple stakeholders' perspectives, focused on classroom learning and implementation (Penuel et al. 2011).

The Combination-Of-Perspectives (COOP) model (Könings et al. 2005) visualises the different stakeholders involved (see Fig. 1). Instructional designers develop blueprints for learning environments (e.g., instructional materials or educational approaches), based on their knowledge and ideas about effective, efficient and appealing learning and teaching. Mostly, it is the role of the teacher to build or create the concrete learning environment for students and translate the blueprint into practice. Furthermore, the model visualises that students' perceptions of the learning environment influence learning and quality of learning outcomes. Moreover, the COOP-model depicts the proposed reciprocal relationships between stakeholders: Student involvement in the design process should be promoted by enabling them to express their perceptions of the learning environment to teachers and designers. Furthermore, intensifying the collaboration between teachers and designers is proposed.

In the model, the dotted arrows depict feedback loops, which seem unidirectional. This, however, does not imply that only the receivers of information or feedback profit from this exchange. In this Special Issue it becomes apparent that communication and collaboration between stakeholders is likely to be valuable for all involved. Because of mutual learning from each other's perspectives, a win-win situation arises.

There is a need to develop and systematically test new strategies to strengthen collaboration and gear perspectives of designers, teachers and students to one another, but research on how to organize this is still limited. Initiatives to include different stakeholders as design partners in instructional design are mostly called participatory design, but are also described as co-creation, student voice, and democratic education. In this literature, the real involvement of students in the design process and decision-making is often rather limited. Druin (2002) describes four possible roles for students: As a user (who can be observed or assessed), as a tester (who is also asked for comments), as an informant (who offers feedback and input), and as a design partner (considered as equal stakeholder in the 


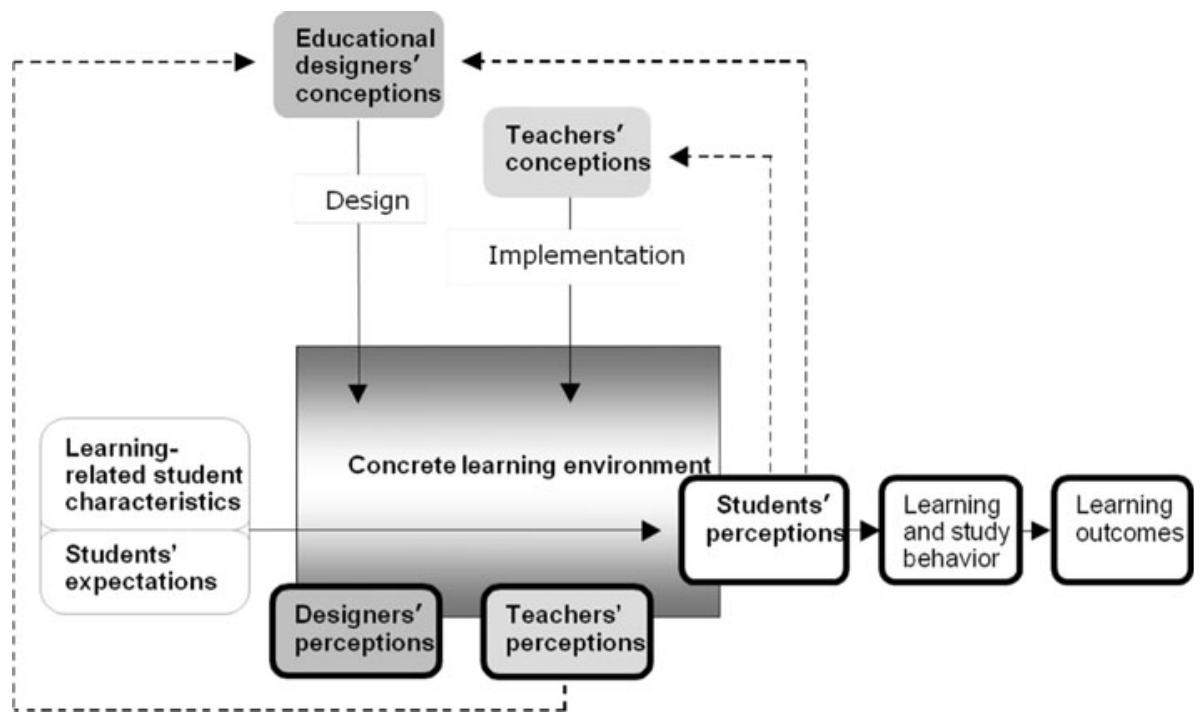

Fig. 1 Combination-of-perspectives model

design process). The student as a user is the most common role of students (ibid). Bovill and Bulley (2011) developed a model called "Ladder of student participation in curriculum design". It includes eight rungs with different levels of participatory design on a continuum from dictated curriculum with no interaction, via some choice and influence for students, to students full in control. Considering students as a design partner (Druin 2002), however, does not imply that we should aim to give students full control over the instructional design. Although there is a strong need for more student participation in instructional design processes, teachers and designers have to be the gatekeepers to the curriculum (Bovill and Bulley 2011) and evidence from educational research should be incorporated in the instructional design of learning environments. Moreover, students' expertise for instructional design is limited, as many of them are not yet able to control their learning in a way that is optimal for learning (Kirschner and Van Merriënboer 2013). They might misregulate their learning, prefer ways of learning that are not always best for them and have difficulties to choose learning activities in case of too many options (ibid). Participatory design does not aim to reach self-determined learning, but stresses collaboration between stakeholders. Stakeholders work on better understanding each other's perspectives and improving instructional design by close collaboration.

There is a need for more evidence on how to best involve different stakeholders and how these initiatives affect the participants. Three types of beneficial effects are to be expected from design collaboration between educational designers, teachers, and students. First, it is ultimately expected to improve quality of learning processes and outcomes by creating more effective learning environments. As research in this field is still in its early stages, studies are mostly focused on the process and there are almost no studies that inform about effects on learning outcomes (Könings et al. 2011b). Second, participatory design is likely to improve metacognition and reflection on learning and teaching. Students and academic staff gain a deeper understanding and awareness of learning (Bovill et al. 2011). Students are more engaged, have higher levels of individual responsibility, and are more motivated and self-confident (Bovill, 2013). And, it provides teachers and designers 
with more insight in the effects of their education on students (Könings et al. 2011b). Third, participants are likely to develop participatory, collaborative, and democratic competencies. Students learn to discuss about differences between themselves and others, and deal with discomfort and conflicting ideas; they revise their sense of self and become stronger, more serious students (Cohen et al. 2013). Students and academic staff develop a different relationship, which is more on the level of colleagues, with more shared responsibility and shared understanding of struggles (Bovill et al. 2011; Katsenou et al. 2013).

The contributions in this Special Issue describe a broad range of different initiatives for supporting and structuring collaboration between designers and/or teachers and/or students. Article 1 describes the very first phase of accounting for different perspectives, by exploring existing differences between perspectives in detail. The other articles all use a different approach to integrating the perspectives of different stakeholders This can be in the form of direct collaboration in a participatory design setting (articles 2 and 3), but information from other stakeholders can also be used in a more indirect way by incorporating information into tools (articles 4 and 5). The articles will be briefly discussed in the next section.

\section{Constituent papers}

The first article, Differences between students' and teachers' perceptions of education: Profiles to describe congruence and friction (Könings et al. 2014) describes a study on students' and teachers' perceptions of their learning environment in secondary education. In case of large discrepancies between their perceptions, interventions using participatory design would be most urgent. It is investigated which patterns can be found in the differences between perceptions of students and teachers. This is linked to the theory of constructive and destructive friction by Vermunt and Verloop (1999). Questionnaire data were analysed from 994 students and 136 teachers. Profiles were identified with respect to the magnitude of differences in perceptions. Results revealed three student profiles and two teacher profiles. Subgroups of students and teachers provide a comprehensive picture of those who are at risk because of too large differences in perceptions. The theory of Vermunt and Verloop is extended by introducing the concept of destructive congruence. The study shows that detailed investigation of perceptions of stakeholders helps indicating subgroups of students and teachers that are at highest need for optimising the learning environment by participatory design.

The second article Multiplying perspectives and improving practice: What can happen when undergraduate students collaborate with college faculty to explore teaching and learning by Cook-Sather (2014) reports a participatory design initiative in higher education. A program was implemented in which undergraduate students and college faculty members where partners in exploring teaching and learning. This semester-long partnership was aimed to broaden interactions, which typically are limited to learning content, towards examining, affirming and possibly revising pedagogical practice. The study examined what happens when students and teachers are inclined to engage in a dialogue with each other about teaching and learning. Additionally, it is investigated how such dialogic engagement can be incorporated into students' and teachers' practice. This is an important question when thinking about sustainability of participatory design initiatives, which ideally should not be organised on an occasional basis, but as a continuous process. Data from discussions between participants and feedback from them show that dialogues in 
partnership between students and teachers facilitate multiplying their perspectives in ways that have the potential to improve teaching and learning. Participants gain new insights in each other's experiences and angles of vision. These insights deepen self-awareness and understanding of others' experiences and perspectives. Participants are inclined to embrace more engaged and collaborative approaches to teaching and learning.

The third article Structured approaches to participatory design for children: Can targeting the needs of children with autism provide benefits for a broader child population? (Benton and Johnson 2014) investigates whether mainstream children in secondary education benefit from using a participatory design approach that offers more structure and support, as it was originally developed for children with autism. In the study, four design teams worked on the development of a maths game: Two teams including children with autism and two teams with mainstream school children. Results show that all teams benefited from the structured and supportive approach, although benefits varied between and within the different groups, with some children requiring the additional structure/ support more than others. The study stresses that participatory design is a new initiative for most students, requiring skills that cannot be taken for granted. Extra support or training might be necessary.

The fourth and fifth article present alternative approaches to the direct, bidirectional collaboration as described in articles 2 and 3: Accounting for other stakeholders by using their perspectives in developing instructional design tools. The article How to make guided discovery learning practical for student teachers (Janssen et al. 2014) reports a teacher training trajectory in which knowledge and experiences from both expert teachers and students is incorporated, aimed at making guided discovery learning (GDL) practical for student biology teachers. Instructional design protocols of expert teachers are analysed to identify practical heuristics for designing lessons. Additionally, students' responses to lessons were input in the development of the training. These perspectives were integrated into a teacher training program for 11 student biology teachers in which they applied the heuristics and stepwise extended their teaching repertoire in the direction of GDL. Effects on quality of their design processes and resulting lesson plans and their motivation were positive. Teachers are well able to design lessons and use heuristics, with increased motivation. This article shows that even in an indirect way, stakeholders can benefit from the expertise and experiences of others.

In the fifth article Getting immersed in teacher and student perspectives? Facilitating analytical competence using video cases in teacher education (Goeze et al. 2014) a study with a newly developed video case-based learning environment is presented. In the study, pre-service teachers are trained in becoming immersed in student and teacher perspectives. In a $2 \times 2$ design, pre-service teachers studied video-cases of classroom situations, with extra support for perspective taking and/or conceptual knowledge by added hyperlinks in the learning environment. The findings reveal that both forms of instructional support were beneficial for reaching a better understanding of the cases. Most interestingly, hyperlinks to multiple perspectives led to increased immersion as observable in small group case discussions and written post-tests. This kind of integrating perspectives, thus, might contribute to improved quality of instruction. Teachers benefit from it by developing new insights and skills, although without direct collaboration with students. This seems and interesting and promising new tool for teacher training.

Two commentaries conclude this Special Issue. Barry Fishman from the University of Michigan and Allison Druin from University of Maryland critically discuss the different contributions. 


\section{Conclusions and future directions}

Table 1 presents an overview of the articles in this special issue. The concepts of the COOP-model are used to draw general conclusions and define directions for future research.

First, the articles differed in the kind of outcome measures used. According to the COOP-model, a learning environment affects perceptions of all stakeholders, which subsequently influence learning behaviours in the learning environment and finally the learning outcomes (i.e., effectiveness of instruction). The first three articles focused on perceptions of students and teachers, while the fourth and fifth article did not investigate perceptions, but primarily dealt with effects on learning behaviour of teachers and their learning outcomes and performances in terms of produced lesson plans or analysis of a case.

Second, this overview of measures shows that all articles had a limited scope with respect to the stakeholders involved. They either investigated perceptions of two different stakeholders or different outcomes for one stakeholder (i.e., learning behaviour and outcomes of teachers). Effects for educational designers were not included in any of the reported studies, but teachers can have the role of designers as well. There is a need for more research in which influences on students' learning behaviour and outcomes are investigated. This would provide evidence for the effects of participatory design on quality of learning and would strengthen the claim that participatory design deserves a more prominent place in instructional design processes. Future research should also make clear how far-reaching effects are: Improving perceptions and satisfaction, better learning because of improved metacognition and reflection, and/or objectively better instruction for learning? Additionally, it would be beneficial when future research includes effect measures for all stakeholders, to give a comprehensive overview of effects of participatory design on all involved in the process.

Third, the articles varied in their focus. The COOP-model includes the design, implementation and the concrete learning environment as elements of an instructional design. While the first article investigated students' perceptions of the learning environment in which they were taught (but without participatory design intervention), the second and third article examined perceptions of the collaborative, participatory design process. Articles 4 and 5 describe effects of the participatory design process on teacher skills, which are prerequisite for good teaching, but the teaching activity was not the topic of study. The focus of all articles, except article 1, was on the design process as such and not on the resulting learning environment. Collaboration during participatory design of instruction was examined, which provides valuable information about the quality of this process. This is necessary evidence before starting the implementation of the participatory developed instruction. However, it would be highly valuable to examine how this instruction is implemented. Can this also be done in a participatory way as well? And, how is this "new" learning environment perceived and what learning behaviour and outcomes does it evoke?

Finally, articles also varied on the level on which the interventions took place. Students' contribution in collaboration with teachers was the main focus in articles 2 and 3. Both papers show that collaboration is a learning process for students that might need extra support or training. Teachers improved their skills in the studies reported in articles 4 and 5: By using the information of the perspectives of other stakeholders, they improved their teaching. This shows that effectively making use of experiences and expertise from different stakeholders requires skills that should not be taken for granted. To reach positive outcomes of participatory design, students, teachers and designers need to be trained for 


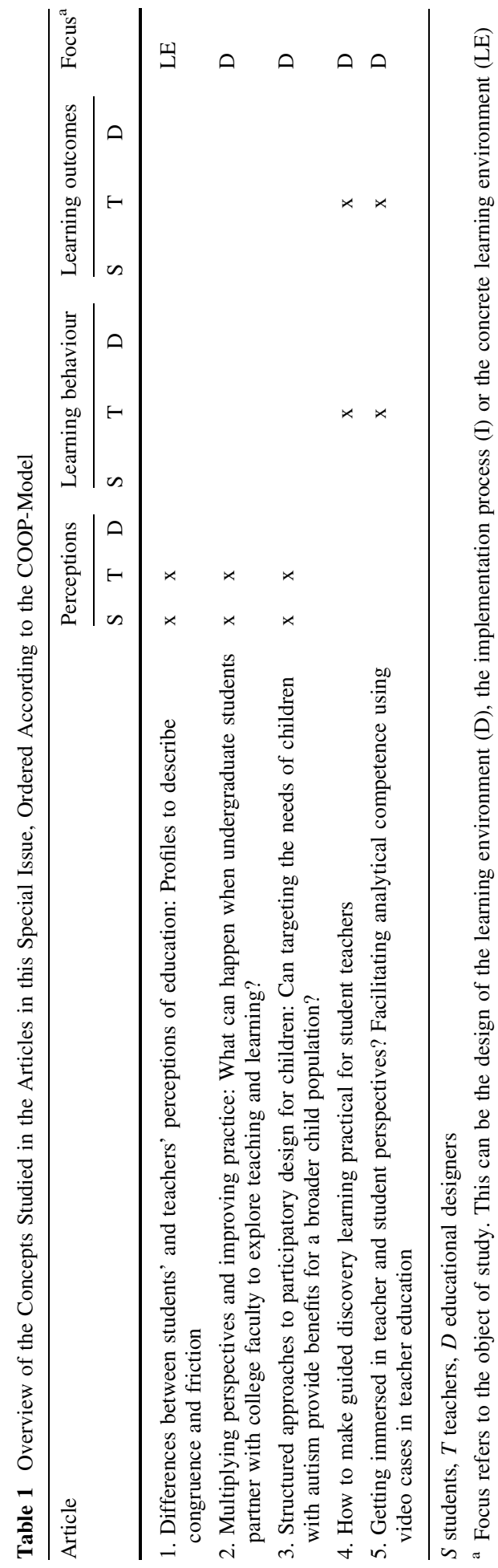


this collaboration. More research is needed to provide empirically based guidelines for such training programs.

Taken together, the articles in this special issue show a variety of initiatives for participatory designing instruction, investigating mainly the design process from the perspectives of students and teachers. The findings provide clues for further development of the COOP-model, to stress that participatory design is a reciprocal process for all stakeholders involved, which also stimulates professional learning by teachers and educational designers. In the process from collaboratively, participatory designing instruction to its implementation, the main directions for future research are: (1) Which approaches are most suitable to support and train stakeholders involved to effectively contribute in the participatory design process? (2) What are the effects of participatory design in the implementations of a learning environment and what role can be given to stakeholders in this translation from design to practice? And, (3) what are the effects of participatory designed instruction on students' learning behaviour and outcomes, and professional development for other involved stakeholders?

\section{References}

Benton, L., \& Johnson, H. (2014). Structured approaches to participatory design for children: Can targeting the needs of children with autism provide benefits for a broader child population? Instructional Science. doi:10.1007/s11251-013-9297-y

Bovill, C. (2013). An investigation of co-created curricula within higher education in the UK, Ireland and the USA. Innovations in Education and Teaching International. doi:10.1080/14703297.2013.770264

Bovill, C., \& Bulley, C. J. (2011). A model of active student participations in curriculum design: Exploring desirability and possibility. In C. Rust (Ed.), Improving student learning global theories and local practices: Institutional, disciplinary and cultural variations (pp. 176-188). Oxford: The Oxford Centre for Staff and Educational Development.

Bovill, C., Cook-Sather, A., \& Felten, P. (2011). Students as co-creators of teaching approaches, course design, and curricula: Implications for academic developers. International Journal for Academic Development, 16, 133-145. doi:10.1080/1360144X.2011.568690.

Cohen, J., Cook-Sather, A., Lesnick, A., Alter, Z., Awkward, R., Decius, F., et al. (2013). Students as leaders and learners: Towards self-authorship and social change on a college campus. Innovations in Education and Teaching International, 50, 3-13. doi:10.1080/14703297.2012.746511.

Cook-Sather, A. (2003, March/April). Listening to students about learning differences. Teaching Exceptional Children, 22-26.

Cook-Sather, A. (2014). Multiplying perspectives and improving practice: what can happen when undergraduate students collaborate with college faculty to explore teaching and learning. Instructional Science. doi:10.1007/s11251-013-9292-3

Doyle, W. (1977). Paradigms for research on teacher effectiveness. In L. S. Schulman (Ed.), Review of research in education (pp. 163-197). Itasca: F.E. Peacock.

Druin, A. (2002). The role of children in the design of new technology. Behaviour and Information Technology, 21, 1-25.

Elen, J., \& Lowyck, J. (1999). Metacognitive instructional knowledge: Cognitive mediation and instructional design. Journal of Structural Learning \& Intelligent Systems, 13, 145-169.

Entwistle, N. J. (1991). Approaches to learning and perceptions of the learning environment. Higher Education, 22, 201-204.

Fishman, B. J., \& Krajcik, J. (2003). What does it mean to create sustainable science curriculum innovations? A commentary. Science Education, 87, 564-5743. doi:10.1002/sce.10088.

Goeze, A., Zottmann, J., Vogel, F., Fischer, F., \& Schrader, J. (2014). Getting immersed in teacher and student perspectives? Facilitating analytical competence using video cases in teacher education. Instructional Science. doi:10.1007/s11251-013-9304-3

Janssen, F., Westbroek, H., \& Van Driel, J. (2014). How to make guided discovery learning practical for student teachers. Instructional Science. doi:10.1007/s11251-013-9296-Z

Katsenou, C., Flogaitis, E., \& Liarakou, G. (2013). Exploring pupil participation within a sustainable school. Cambridge Journal of Education, 43, 243-258. doi:10.1080/0305764X.2013.774320. 
Kirschner, P. A., \& Van Merriënboer, J. J. G. (2013). Do learners really know best? Urban legends in education. Educational Psychologist, 48, 169-183. doi:10.1080/00461520.2013.804395.

Könings, K. D., Brand-Gruwel, S., \& van Merriënboer, J. J. G. (2005). Towards more powerful learning environments through combining the perspectives of designers, teachers and students. British Journal of Educational Psychology, 75(4), 645-660. doi:10.1348/000709905X43616.

Könings, K. D., Brand-Gruwel, S., \& van Merriënboer, J. J. G. (2007). Teachers' Perspective on Innovations: Implications for Educational Design. Teaching and Teacher Education, 23, 985-997. doi:10. 1016/j.tate.2006.06.004.

Könings, K. D., Brand-Gruwel, S., \& van Merriënboer, J. J. G. (2011a). The Match between Students' Lesson Perceptions and Desires: Relations with Student Characteristics and the Importance of Motivation. Educational Research, 53, 439-457. doi:10.1080/00131881.2011.625155.

Könings, K. D., Brand-Gruwel, S., \& van Merriënboer, J. J. G. (2011b). Participatory Instructional redesign by students and teachers in secondary education: Effects on perceptions of instruction. Instructional Science, 39, 737-762. doi:10.1007/s11251-010-9152-3.

Könings, K. D., Seidel, T., Brand-Gruwel, S., \& Van Merriënboer (2014). Differences between students' and teachers' perceptions of education: Profiles to describe congruence and friction. Instructional Science. doi:10.1007/s1 1251-013-9294-1

Mitra, D. L. (2004). The significance of students: Can increasing "student voice" in schools lead to gains in youth development? Teachers College Record, 106, 651-688. doi:10.1111/j.1467-9620.2004.00354.x.

Penuel, W. R., Fishman, B. J., Cheng, B. H., \& Sabelli, N. (2011). Organizing research and development at the intersection of learning, implementation, and design. Educational Researcher, 40, 331-337. doi:10. 3102/0013189X11421826.

Roeser, R. W., Eccles, J. S., \& Sameroff, A. J. (2000). School as a context of early adolescents' academic and social-emotional development: A summary of research findings. The Elementary School Journal, $100,443-471$.

Rudduck, J., \& McIntyre, D. (2007). Improving learning through consulting pupils. London: Routledge.

Smyth, J., \& Fasoli, L. (2007). Climbing over the rocks in the road to student engagement and learning in a challenging high school in Australia. Educational Research, 49, 273-295. doi:10.1080/00131880701 550565 .

Vermetten, Y. J., Vermunt, J. D., \& Lodewijks, H. G. (2002). Powerful learning environments? How university students differ in their response to instructional measures. Learning and Instruction, 12, 263-284.

Vermunt, J. D., \& Verloop, N. (1999). Congruence and friction between learning and teaching. Learning and Instruction, 9, 257-280. 